\title{
The Stickler syndrome: Genotype/phenotype correlation in 10 families with Stickler syndrome resulting from seven mutations in the type II collagen gene locus COL2A1
}

Ruth M. Liberfarb, MD, $P h D^{1}$, Howard P. Levy, MD, PhD', Peter S. Rose, $M D^{3}$, Douglas J. Wilkin, $P h D^{4}$, Joie Davis, MSN, CPNP ${ }^{5}$, Joan Z. Balog, RN, MSN ${ }^{5}$, Andrew J. Griffith, MD, PhD ${ }^{6}$, Yvonne M. Szymko-Bennett, PhD ${ }^{6}$, Jennifer J. Johnston, $P h D^{5}$, and Clair A. Francomano, $M D^{7}$

\begin{abstract}
Purpose: To evaluate a cohort of clinically diagnosed Stickler patients in which the causative COL2A1 mutation has been identified, determine the prevalence of clinical features in this group as a whole and as a function of age, and look for genotype/phenotype correlations. Methods: Review of medical records, clinical evaluations, and mutational analyses of clinically diagnosed Stickler patients. Results: Patients with seven defined COL2A1 mutations had similar phenotypes, though both inter- and intrafamilial variability were apparent and extensive. The prevalence of certain clinical features was a function of age. Conclusion: Although the molecular determination of a COL2A1 mutation can predict the occurrence of Stickler syndrome, the variability observed in the families described here makes it difficult to predict the severity of the phenotype on the basis of genotype. Genet Med 2003:5(1):21-27.
\end{abstract}

Key Words: Stickler syndrome, genotype/phenotype correlation, prevalence of clinical features

The Stickler syndrome (also called hereditary progressive arthro-ophthalmopathy) is a dominantly inherited disorder of connective tissue first recognized by Stickler and colleagues in a family with midfacial hypoplasia, hearing loss, vitreoretinal degeneration, joint hypermobility, and premature osteoarthritis. ${ }^{1,2}$ The Stickler syndrome is not rare, ${ }^{3}$ having been described as the most common autosomal dominant connective tissue dysplasia in the North American Midwest. ${ }^{4}$ Subsequent reports have highlighted the intra- and interfamilial variability in the syndrome and expanded the details of the phenotype affecting the ocular, craniofacial, auditory, and musculoskeletal systems and the heart. ${ }^{4-17}$ The problems affecting the ocular system include vitreoretinal degeneration, retinal holes and detachments, myopia, cataracts, and glaucoma. Craniofacial involvement includes maxillary hypoplasia, flattening or wid-

From the ${ }^{1}$ Genetics and Teratology Unit, Massachusetts General Hospital, Boston, Massachusetts; ${ }^{2}$ Department of Internal Medicine, Johns Hopkins University School of Medicine, Baltimore, Maryland; ${ }^{3}$ Department of Orthopedic Surgery, Mayo Graduate School of Medicine, Rochester, Minnesota; ${ }^{4}$ Microarray Core Facility, Cedars-Sinai Medical Center, Los Angeles, California; ${ }^{5}$ National Human Genome Research Institute/Medical Genetics Branch, National Institutes of Health, Bethesda, Maryland; ${ }^{6}$ National Institute on Deafness and Other Communication Disorders, National Institutes of Health, Bethesda, Maryland; and ${ }^{7}$ Laboratory of Genetics, National Institute on Aging, National Institutes of Health, Baltimore, Maryland.

Ruth M. Liberfarb, MD, PhD, Genetics and Teratology Unit, Warren 801, Massachusetts General Hospital, 55 Fruit Street, Boston, MA 02114.

Received: August 19, 2002.

Accepted: October 30, 2002.

DOI: 10.1097/01.GIM.0000048704.65405.D8 ening of the nasal bridge, micro/retrognathia, and palatal abnormalities such as highly arched palate, submucous cleft palate, bifid uvula, and open posterior cleft palate. High-frequency sensorineural hearing loss (HFSNHL) and hypermobile tympanic membranes are frequent manifestations involving the auditory system. Musculoskeletal system alterations include joint hypermobility, mild spondyloepiphyseal dysplasia, hip and spine abnormalities, pectus excavatum or carinatum, early-onset degenerative arthritis, and chronic musculoskeletal pain. Mitral valve prolapse is the only cardiac involvement.

Early genetic studies demonstrated linkage of the type II collagen gene locus, COL2A1, and Stickler syndrome, ${ }^{18}$ and the identification of a mutation in this gene in Stickler syndrome subsequently confirmed this as the causative gene. ${ }^{19,20} \mathrm{~A}$ variety of mutations spread throughout the entire COL2A1 gene have been identified in families with the Stickler syndrome. ${ }^{21-31}$ Most of the Stickler COL2A1 mutations noted to date result in the introduction of a premature stop codon, suggesting that the phenotype usually results from a quantitative defect in type II procollagen biosynthesis either because of the nonsense-mediated mRNA decay pathway or failure of chain association. COL2A1 mutations associated with phenotypes more severe than the Stickler syndrome such as achondrogenesis type II, hypochondrogenesis, spondyloepiphyseal dysplasia congenita, and Kniest dysplasia result from missense mutations that cause defects in the structure of type II collagen protein. ${ }^{32}$ 
Stickler syndrome is genetically heterogeneous as mutations in COL2A1 (12q13) account for only about 70\% of reported Stickler families. ${ }^{33-37}$ Among the remaining families, linkage to COL11A1 (1p21) $)^{37-39}$ or a mutation in the COL11A2 (6p21) gene locus of type XI collagen in a nonocular form of Stickler syndrome has been reported. ${ }^{37,40}$ Further genetic heterogeneity is likely, as linkage to the three Stickler-related genes has been excluded in some affected families. ${ }^{15,38}$

Stickler syndrome has been classified into two subtypes to reflect both the locus heterogeneity and differences of vitreous phenotype: type 1 or membranous vitreous type is due exclusively to mutations in COL2A1; type 2 or the beaded vitreous type is due to mutations in other genes. ${ }^{41,42}$ In an alternative nosology, three variants of Stickler syndrome are defined on the basis of ocular phenotype and molecular linkage: type I with type 1 vitreous phenotype is linked to COL2A1; type II with no ocular involvement is linked to COL11A2; type III has type 2 vitreous phenotype and has been linked to COL11A1.43-45

No formal diagnostic criteria have been established for Stickler syndrome. Snead and Yates ${ }^{42}$ proposed diagnostic criteria requiring involvement in various organ systems (for example, congenital vitreous anomaly and, in addition, manifestation in three of the classically affected systems), but these criteria are based on clinical diagnoses lacking defined mutations. Rose et al. ${ }^{9,11}$ proposed diagnostic criteria based on clinical data from patients evaluated at the National Institutes of Health (NIH) whose clinical diagnosis of Stickler syndrome has been molecularly confirmed by finding specific mutations in COL2A1.

In this report, we present clinical and molecular data from an ongoing study of 200 individuals in 64 families with the clinical diagnosis of Stickler syndrome; we focus on 10 families with defined mutations in COL2A1.

\section{METHODS}

\section{Patients}

We identified 200 individuals from 64 unrelated families in which the proband was diagnosed with Stickler syndrome based on clinical findings. In 33 of these families, the proband was identified between 1976 through 1992 by one of us (R.M.L.) after referral for treatment of retinal detachments. These 33 families were contacted in 1998 by R.M.L. and invited to enroll in the NIH study. The other 31 families were either self-referred from the support group "Stickler Involved People" or referred by other geneticists to the Medical Genetics Clinic of the NIH.

The goals of the study included establishing the genetic caus$\mathrm{e}(\mathrm{s})$ and clinical manifestations of the Stickler syndrome in a large cohort of clinically diagnosed Stickler subjects from multiple unrelated families, assessing the relationship between specific mutations and their associated disease phenotypes and improving the diagnosis and treatment of the disorder.

Subjects requested medical records from physicians caring for their ocular, craniofacial, auditory, musculoskeletal, and heart problems. These records were reviewed to document the clinical features present. Blood was obtained at NIH.

In 47 individuals from 10 families, the clinical diagnosis of Stickler syndrome was confirmed by finding specific mutations in the COL2A1 gene. All of the 47 affected individuals from these 10 families were invited to the NIH genetics clinic for a comprehensive clinical evaluation, and 25 subjects from 6 families came. No priority was given to specific individuals or families. This report presents the clinical evaluations of these 25 individuals and the results of medical record review from the remaining affected family members.

\section{Clinical evaluation}

The clinical evaluation included a physical examination by a medical geneticist familiar with the features of Stickler syndrome and related connective tissue disorders (C.A.F., H.P.L., or R.M.L.), an echocardiogram, an ophthalmologic examination, an audiogram (Y.M.S.-B.), an otorhinolaryngologic examination (A.J.G.), and a musculoskeletal examination with skeletal $\mathrm{x}$-rays of the spine and long bones. If a subject had not already sent in a blood specimen for mutational analysis, blood was drawn as part of the NIH evaluation and sent to the research laboratory at NIH.

\section{Establishment of clinical criteria for evaluation and diagnosis}

Facies

The presence of characteristic facies defined as the triad of midfacial hypoplasia, a flattened nasal bridge, and micro/retrognathia was a subjective determination. Figure 1 illustrates the characteristic facies in profile in three generations of affected relatives (grandmother 50 years old; daughter 27 years old; and granddaughter 4 years old). The characteristic facial appearance is typically more pronounced in children.

\section{High-frequency sensorineural hearing loss}

Age-specific thresholds for HFSNHL were developed in the course of the study based on normative data for 8-kHz thresh$\mathrm{olds}^{46}$ and age- and gender-specific reference ranges for hearing level and change in hearing level for men and women from 17 to 90 years old. ${ }^{47}$ HFSNHL was defined as a threshold

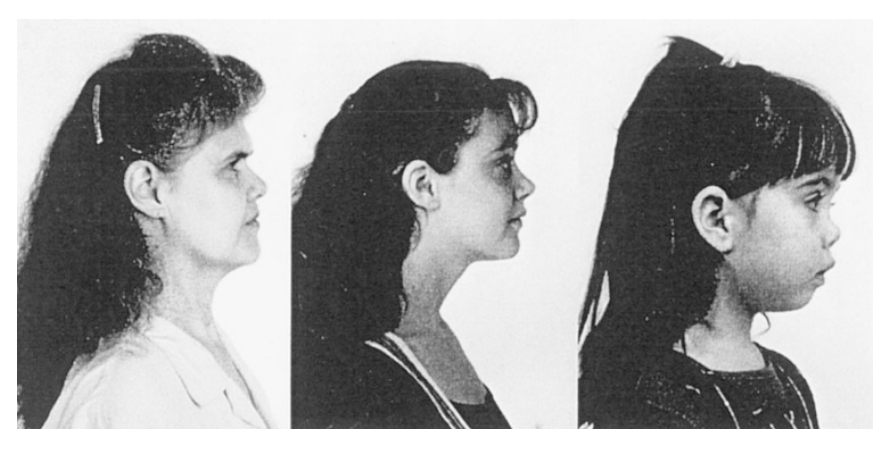

Fig. 1 Characteristic facies (midfacial hypoplasia, depressed nasal bridge, and micro/ retrognathia) of the Stickler syndrome as seen in profile in three generations of affected relatives (grandmother, 50 years old, on left; daughter, 27 years old, in middle; and granddaughter, 4 years old, on right). 
greater than or equal to $20 \mathrm{~dB}$ at any frequency from 4 to $8 \mathrm{kHz}$ for age $<20$ years, a threshold greater than or equal to $30 \mathrm{~dB}$ at any frequency from 4 to $8 \mathrm{kHz}$ for age $20-30$ years, and a threshold greater than or equal to $40 \mathrm{~dB}$ at any frequency from 4 to $8 \mathrm{kHz}$ for age $>40$ years.

\section{Hypermobile tympanic membranes}

Tympanic membrane mobility was measured by tympanometry. ${ }^{48-50}$

\section{Hypermobile joints}

Joint mobility was assessed objectively with the Beighton scoring system. ${ }^{51}$

\section{Osteoarthritis}

Osteoarthritis was defined as articular pain in conjunction with joint space narrowing, osteophytes, or subchondral sclerosis or cysts.

\section{Scoliosis}

Scoliosis was defined as a sagittal curvature of the spine greater than 10 degrees as measured by the technique of Cobb. ${ }^{52}$

\section{Scheuermann-like kyphotic deformity}

Scheuermann-like kyphotic deformity was defined as a focal kyphosis with 5 degrees or greater vertebral body wedging across three consecutive vertebral bodies (for a minimum 15 degrees focal kyphosis). ${ }^{53}$

\section{Mitral valve prolapse}

Mitral valve prolapse was diagnosed on recently revised twodimensional echocardiographic criteria. ${ }^{54}$

\section{Molecular analysis}

COL2A1 has 10 "in frame" CGA codons mutable to TGA stop codons via a methylation-deamination mechanism. Wilkin et al. ${ }^{16}$ screened the CGA sites and identified TGA nonsense mutations in 8 of 40 probands examined; 8 of these families are included in this current study (Families 1, 3, 5, 6, 7, 8, 9 , and 10). These nonsense mutations occurred at 5 of the 10 in-frame CGA codons and were found in exons 7 (Family 1), 15 (Family 3), 23 (Families 5, 6, and 7), 28 (Family 8), and 40 (Families 9 and 10). Mutations had not been identified in 2 of the 10 families (Families 2 and 4). Analysis of the COL2A1 gene in these families, using denaturing high-performance liquid chromatography and sequence analysis, identified two mutations. The following oligonucleotide sequences were used for amplification and sequencing of exons 12 and 21:

11f 5' GTAAGTATCACGGGTGAGAAG 3'

13r 5' GTCTTTGATAAACCTTCCTGGAG 3'

21f 5' TTCTCACTCACTGCCTCTCCTCCC 3'

23r 5' AGGGTCTGAAGCCAAGGGCAACAGCAGCTC 3'

In Family 2, a 1-bp deletion was found in exon 12, and in Family 4, a 5-bp deletion was found in exon 22.

\section{Review of clinical records}

We reviewed medical records of 47 affected subjects from the 10 families for whom the clinical diagnosis of the Stickler syndrome was associated with mutations in the COL2A1 gene, to document the clinical features of the Stickler syndrome.

\section{RESULTS}

Table 1 summarizes the genotypes and phenotypes in the 47 affected members of the 10 families with seven defined mutations in the COL2A1 gene based on review of medical records as well as clinical evaluations at NIH of 25 affected individuals from 6 of the 10 families (Families 2, 3, 4, 5, 6, and 9). In the group of 25 evaluated at NIH, there are 9 males and 16 females ranging in age from 2 to 73 years with a mean age of 34.7 years. Three members of these families were less than 5 years old and had incomplete evaluations. Three additional members of the mutation-bearing families were also evaluated at $\mathrm{NIH}$ and found not to have the COL2A1 mutation causing Stickler syndrome in their families.

The classic Stickler phenotype was expressed clinically in all 10 Stickler families with COL2A1 mutations. All individuals with the molecular diagnosis of Stickler syndrome who could be examined at NIH had vitreous degeneration type 1. Some individuals could not be examined (young age or disability) or previous surgical procedures. Vitreous changes in affected members of families not seen at NIH could not be documented fully. Myopia was reported in 41 of the 47 affected subjects with the molecular diagnosis of Stickler syndrome, with no refraction information for the remaining 6 affected subjects. Twenty-four of the 41 had specific refractions at NIH: $42 \%$ were mildly myopic (refraction $<-5$ diopters), $17 \%$ were moderately myopic (refraction -5 to -8 diopters), $33 \%$ were severely myopic (refraction $>-8$ diopters), and $8 \%$ had a mixture (moderately myopic in one eye and mild or severe in the other).

Considerable interfamilial and intrafamilial variability in clinical expression is apparent when one compares clinical features such as cleft palate and myopia in unrelated families with the same molecular diagnosis. For example, Families 5, 6, and 7 had a single base substitution in Arg333 causing a premature stop codon in exon 23 (R333X). In Family 5, the proband had a repaired cleft palate. In Family 6, none of the three examined had palate abnormalities, and in Family 7, one of five had a cleft palate and one of five had a bifid uvula. In Family 5 the only affected person had mild/moderate myopia. In Family 6, three had high myopia; in Family 7, one had mild myopia, two had mild/moderate myopia, one had mild/high myopia, and one had high myopia.

Families 9 and 10 in our study have the same mutation, R732X in exon 40. In Family 9, all three affected relatives had abnormal palates: one had a repaired cleft palate, one had a submucous cleft palate, and the third had a bifid uvula and a submucous cleft palate; in Family 10, two of four had repaired cleft palate. In Family 9, all three affected relatives were myo- 
Table 1

Summary of genotypes and phenotypes in 10 Stickler families with seven defined mutations in the COL2A1 gene

\begin{tabular}{|c|c|c|c|c|c|c|c|c|c|c|c|c|c|}
\hline Family & $\begin{array}{l}\text { No. } \\
\text { seen at } \\
\text { NIH/ } \\
\text { No. } \\
\text { affected }\end{array}$ & Exon & Nucleotide $^{a}$ & Amino acid $b$ & Myopia & $\begin{array}{l}\mathrm{RH} / \\
\mathrm{RD}\end{array}$ & CAT & $\mathrm{MH}$ & $\begin{array}{c}\mathrm{CP} / \mathrm{BU} / \\
\mathrm{SMCP} / \\
\mathrm{RS}\end{array}$ & SNHL & $\mathrm{HJ}$ & EODJD & $\begin{array}{c}\text { Skeletal } \\
\text { abnormalities }\end{array}$ \\
\hline 1 & $0 / 2$ & 7 & $625 \mathrm{C}>\mathrm{T}$ & R9X & 2 & 2 & $1\left(1^{\star}\right)$ & 2 & 2 & $1\left(1^{\star}\right)$ & $1\left(1^{\star}\right)$ & $\left(2^{\star}\right)$ & $\left(2^{*}\right)$ \\
\hline 2 & $8 / 8$ & 12 & 883delC & L95fsX107 & 8 & 4 & 3 & 8 & 8 & 5 & $5\left(1^{*}\right)$ & 4 & 5 \\
\hline 3 & $4 / 11$ & 15 & $1030 \mathrm{C}>\mathrm{T}$ & $\mathrm{R} 144 \mathrm{X}$ & $8\left(3^{*}\right)$ & $4\left(3^{*}\right)$ & $5\left(2^{\star}\right)$ & 4 & $7\left(3^{*}\right)$ & $6\left(5^{*}\right)$ & 3 & $3\left(6^{*}\right)$ & $4\left(7^{\star}\right)$ \\
\hline 4 & $4 / 8$ & 22 & 1563del5 & G322fsX345 & $7\left(1^{\star}\right)$ & 7 & $5\left(1^{\star}\right)$ & $6\left(2^{\star}\right)$ & 4 & $4\left(3^{\star}\right)$ & $3\left(2^{*}\right)$ & $4\left(3^{*}\right)$ & $3\left(1^{*}\right)$ \\
\hline 5 & $0 / 1$ & 23 & $1597 \mathrm{C}>\mathrm{T}$ & $\mathrm{R} 333 \mathrm{X}$ & 1 & 1 & 1 & 1 & 1 & $\left(1^{*}\right)$ & 1 & $\left(1^{*}\right)$ & 1 \\
\hline 6 & $3 / 4$ & 23 & $1597 \mathrm{C}>\mathrm{T}$ & $\mathrm{R} 333 \mathrm{X}$ & $3\left(1^{\star}\right)$ & 4 & 4 & $3\left(1^{\star}\right)$ & $\left(1^{*}\right)$ & $2\left(1^{*}\right)$ & $1\left(1^{*}\right)$ & $1\left(1^{\star}\right)$ & 1 \\
\hline 7 & $3 / 5$ & 23 & $1597 \mathrm{C}>\mathrm{T}$ & $\mathrm{R} 333 \mathrm{X}$ & 5 & 4 & 3 & 5 & 2 & 5 & $4\left(1^{\star}\right)$ & $4\left(1^{\star}\right)$ & $4\left(1^{\star}\right)$ \\
\hline 8 & $0 / 1$ & 28 & $1957 \mathrm{C}>\mathrm{T}$ & $\mathrm{R} 453 \mathrm{X}$ & 1 & 1 & 1 & $\left(1^{\star}\right)$ & 1 & 1 & 1 & 1 & 1 \\
\hline 9 & $3 / 3$ & 40 & $2794 \mathrm{C}>\mathrm{T}$ & $\mathrm{R} 732 \mathrm{X}$ & 3 & 3 & 1 & 1 & 3 & 2 & 0 & 2 & 3 \\
\hline 10 & $0 / 4$ & 40 & $2794 \mathrm{C}>\mathrm{T}$ & $\mathrm{R} 732 \mathrm{X}$ & $3\left(1^{\star}\right)$ & $2\left(2^{\star}\right)$ & $3\left(1^{\star}\right)$ & $1\left(3^{\star}\right)$ & $2\left(2^{\star}\right)$ & $2\left(2^{*}\right)$ & $1\left(3^{\star}\right)$ & $1\left(3^{\star}\right)$ & $1\left(3^{\star}\right)$ \\
\hline
\end{tabular}

$\mathrm{RH} / \mathrm{RD}$, retinal holes or detachments; CAT, cataracts; $\mathrm{MH}$, midfacial hypoplasia; CP/BU/SMCP/RS, cleft palate/bifid uvula/submucous cleft palate/Robin sequence; SNHL, sensorineural hearing loss; HJ, hyperextensible joints; EODJD, early-onset degenerative joint disease; $\left(^{*}\right)$, not determined.

${ }^{a}$ Nucleotide position is from ATG of variant 1 mRNA gi:15149477.

${ }^{b}$ Amino acid position is from the start of the triple helical domain.

pic, two mildly and one with high myopia. In Family 10, three of four affected relatives had an unspecified degree of myopia. There is no information about myopia in the fourth relative.

Table 2 lists the prevalence of clinical features in 25 Stickler patients with defined mutations in COL2A1 who were evaluated at NIH.

Table 2

Prevalence of clinical features in 25 Stickler patients evaluated at NIH with defined mutations in COL2A1

\begin{tabular}{lcc}
\hline & No. & $\%$ \\
\hline Myopia & 25 & 100 \\
Vitreoretinal degeneration & 25 & 100 \\
Retinal holes/detachments & 17 & 68 \\
Cataracts & 10 & 40 \\
Glaucoma & 2 & 8 \\
Midfacial hypoplasia & 18 & 72 \\
Micrognathia & 15 & 60 \\
Cleft palate & 6 & 24 \\
Bifid uvula and/or submucous cleft palate & 8 & 32 \\
Robin sequence & 2 & 8 \\
Sensorineural hearing loss & 19 & 76 \\
Hypermobile tympanic membrane & 6 & 24 \\
Joint hypermobility & 13 & 52 \\
Early-onset degenerative arthritis & 15 & 60 \\
Skeletal abnormalities & 18 & 72 \\
Mitral valve prolapse & 1 & 4 \\
\hline
\end{tabular}

Figure 2 illustrates the prevalence of certain clinical features as a function of age in those 25 subjects with defined mutations in COL2A1 evaluated at NIH. The following clinical features become more prevalent with advancing age: retinal detachments, cataracts, sensorineural hearing loss, early-onset degenerative joint disease, and skeletal abnormalities involving the spine and hips. The degree of myopia (mild, moderate, severe) is not a function of age. However, when the prevalence of retinal detachments was examined as a function of degree of myopia, the prevalence of retinal detachments appeared to increase with increasing severity of myopia. The prevalence of retinal detachment in those with mild myopia was 50\% compared with $75 \%$ in those with moderate or severe myopia and $100 \%$ in those with mixed myopia (one eye moderate and the other eye severe).

Table 3 shows the clinical findings and the diagnostic scores based on Rose and colleagues ${ }^{\prime 9,11}$ proposed diagnostic criteria for each of the 25 subjects evaluated at NIH. This scoring system assigns 1 or 2 points for various clinical findings. Two points are awarded for the presence of a cleft palate, vitreous degeneration or retinal detachment, and/or HFSNHL. One point is awarded for the characteristic facies, hypermobile tympanic membranes, a history of femoral head failure, radiographically demonstrated osteoarthritis before age 40 , spinal deformities, and/or family history or identification of a causative mutation. A score of 5 is necessary to qualify for a diagnosis of Stickler syndrome. All 25 subjects with molecular confirmation of COL2A1 mutations satisfied these diagnostic criteria (mean diagnostic score 7.3). Three of the four affected individuals with diagnostic scores of 5 were 4 years old or younger. Three molecularly excluded relatives evaluated at $\mathrm{NIH}$ did not meet the criteria for diagnosis. It should be noted 

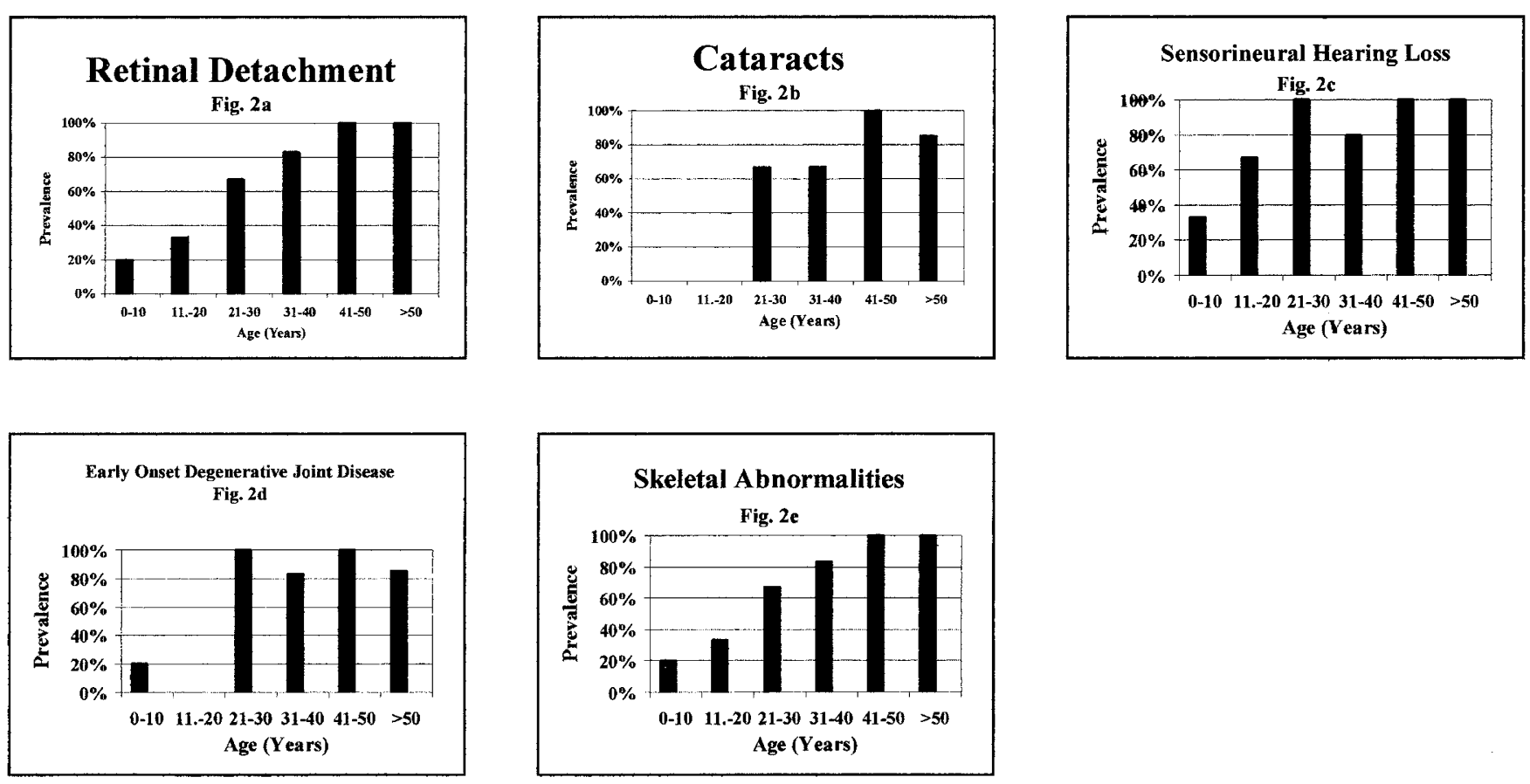

Fig. 2 Bar graphs of the prevalence of certain clinical features as a function of the age of Stickler syndrome-affected patients with specific mutations in COL2A1.

that these diagnostic criteria are based on clinical findings, not on identification of a mutation.

\section{DISCUSSION}

We studied 25 individuals from six families and reviewed the medical records of an additional 22 individuals for these and four additional families whose clinical diagnosis of the Stickler syndrome has been confirmed by finding mutations in COL2A1, the human gene coding for type II procollagen. These mutations are believed to act by haploinsufficiency ${ }^{55}$ creating premature translation stop signals in COL2A1, either via direct nonsense mutation or by frameshift mutation creating a downstream premature stop codon. In a recent study based on data from 316 usable questionnaires returned from individuals who reportedly have Stickler syndrome and belong to support groups in the United Kingdom, the United States, the Netherlands, Canada, and Australia, Stickler et al. ${ }^{56}$ noted that $60 \%$ had retinal detachments, $60 \%$ had cataracts, $41 \%$ had cleft palate, and $55 \%$ had joint hypermobility. The presence or absence of hypermobile tympanic membranes was not reported. Stickler et al. concluded that differences between the clinical manifestations in the whole group and the 31 with defined mutations (27 with mutations in COL2A1 and 4 with mutations in COL11A1) could not be demonstrated.

Reasons for differences in prevalence of clinical features between our 25 patients with defined mutations in COL2A1 studied at NIH and those whose questionnaires were studied by Stickler et al. ${ }^{56}$ could be related to differences in the molecular causes and/or age of patient populations. In the 25 subjects evaluated at $\mathrm{NIH}$, the mean age of the evaluated subjects was
34.7 years; there were 7 subjects less than 16 years old (28\%) and 18 subjects aged 16 years or older (72\%). In the population reported on by Stickler et al., ${ }^{56}$ the mean age was 24.4 years (personal communication); $152(48 \%)$ were 15 years old or younger and 164 were 16 years or older (52\%). We demonstrated that the age of the subjects is an important variable to consider when comparing the prevalence of clinical features in Stickler populations. One would expect to find lower prevalence of retinal detachments and cataracts and higher prevalence of joint hypermobility in the more youthful population reported by Stickler et al. In fact, the prevalence of retinal detachments was slightly lower in the population reported by Stickler et al. (60\% compared with $68 \%$ in our study population). However, the prevalence of cataracts was higher in the Stickler et al. group ( $60 \%$ compared with $40 \%$ in our subjects) and the prevalence of joint hypermobility was about the same in both groups ( $52 \%$ in our study population compared with $55 \%$ in the Stickler et al. group).

As is true for autosomal dominant genetic disorders in general, there is extreme variability in the clinical expression of the Stickler syndrome. This variability is interfamilial as well as intrafamilial. We have shown that interfamilial variation is present even when one compares clinical features such as cleft palate and myopia in unrelated families with the same molecular diagnosis. The interfamilial variability observed in families with the same mutations suggests that the variability may be due to modifying "background" genes elsewhere in the genome or to environmental factors. As a result, molecular biology can assist in the prenatal as well as postnatal diagnosis of the disorder, but it is of little help in predicting the severity of the disease. Further mutational analyses and genotype/pheno- 
Table 3

Diagnostic criteria applied to six Stickler families with COL2A1 mutations evaluated at NIH

\begin{tabular}{|c|c|c|c|c|c|c|c|c|c|c|c|}
\hline Family & Sex & $\begin{array}{l}\text { Age } \\
\text { (yr) }\end{array}$ & $\begin{array}{l}\text { Ocular } \\
\text { RH/RD }\end{array}$ & $\begin{array}{l}\text { Craniofacial } \\
\text { involvement }\end{array}$ & Palate & $\begin{array}{l}\text { Auditory } \\
\text { SNHL }\end{array}$ & HTm & $\begin{array}{l}\text { Skeletal } \\
\text { EODJD }\end{array}$ & Spine & Hip & $\begin{array}{l}\text { Diagnostic } \\
\text { score }\end{array}$ \\
\hline \multirow[t]{8}{*}{2} & M & 12 & $\mathrm{~N}$ & $\mathrm{~N}$ & RS & $\mathrm{Y}$ & $\mathrm{N}$ & $\mathrm{N}$ & $\mathrm{Y}$ & $\mathrm{N}$ & 8 \\
\hline & M & 16 & $\mathrm{Y}$ & $\mathrm{Y}$ & RS & $\mathrm{Y}$ & $\mathrm{Y}$ & $\mathrm{N}$ & $\mathrm{N}$ & $\mathrm{N}$ & 8 \\
\hline & M & 39 & $\mathrm{~N}$ & $\mathrm{~N}$ & $\mathrm{CP}$ & $\mathrm{Y}$ & $\mathrm{Y}$ & $\mathrm{Y}$ & $\mathrm{Y}$ & $\mathrm{Y}$ & 9 \\
\hline & $\mathrm{F}$ & 58 & $\mathrm{Y}$ & $\mathrm{Y}$ & SMCP & $\mathrm{Y}$ & $\mathrm{N}$ & $\mathrm{Y}$ & $\mathrm{N}$ & $\mathrm{N}$ & 9 \\
\hline & M & 59 & $\mathrm{Y}$ & $\mathrm{Y}$ & SMCP & $\mathrm{Y}$ & $\mathrm{Y}$ & $\mathrm{Y}$ & $\mathrm{N}$ & $\mathrm{N}$ & 9 \\
\hline & $\mathrm{F}$ & 33 & $\mathrm{Y}$ & $\mathrm{N}$ & $\mathrm{CP}$ & $\mathrm{Y}$ & $\mathrm{N}$ & $\mathrm{Y}$ & $\mathrm{N}$ & $\mathrm{Y}$ & 9 \\
\hline & $\mathrm{F}$ & 9 & $\mathrm{~N}$ & $\mathrm{~N}$ & $\mathrm{CP}$ & $\mathrm{Y}$ & $\mathrm{N}$ & $\mathrm{N}$ & $\mathrm{Y}$ & $\mathrm{N}$ & 7 \\
\hline & $\mathrm{F}$ & 4 & $\mathrm{~N}$ & $\mathrm{Y}$ & $\mathrm{BU}$ & $\mathrm{N}$ & $\mathrm{N}$ & $\mathrm{N}$ & $\left({ }^{*}\right)$ & $\mathrm{N}$ & 5 \\
\hline \multirow[t]{4}{*}{3} & $\mathrm{~F}$ & 50 & $\mathrm{Y}$ & $\mathrm{N}$ & BU/SMCP & $\mathrm{Y}$ & $\mathrm{Y}$ & $\mathrm{Y}$ & $\mathrm{Y}$ & $\mathrm{N}$ & 9 \\
\hline & $\mathrm{F}$ & 27 & $\mathrm{~N}$ & $\mathrm{~N}$ & $\mathrm{~N}$ & $\mathrm{Y}$ & $\mathrm{Y}$ & $\mathrm{Y}$ & $\mathrm{Y}$ & $\mathrm{N}$ & 7 \\
\hline & $\mathrm{F}$ & 4 & $\mathrm{~N}$ & $\mathrm{Y}$ & $\mathrm{N}$ & $\left({ }^{*}\right)$ & $\mathrm{N}$ & $\mathrm{Y}$ & $\mathrm{N}$ & $\mathrm{N}$ & 5 \\
\hline & $\mathrm{F}$ & 2 & $\mathrm{~N}$ & $\mathrm{Y}$ & SMCP & $\left({ }^{*}\right)$ & $\mathrm{N}$ & $\mathrm{N}$ & $\left({ }^{*}\right)$ & $\mathrm{N}$ & 5 \\
\hline \multirow[t]{4}{*}{4} & $\mathrm{~F}$ & 59 & $\mathrm{Y}$ & $\mathrm{Y}$ & $\mathrm{N}$ & $\mathrm{Y}$ & $\mathrm{N}$ & $\mathrm{Y}$ & $\mathrm{Y}$ & $\mathrm{N}$ & 8 \\
\hline & M & 36 & $\mathrm{Y}$ & Y & $\mathrm{CP}$ & $\mathrm{Y}$ & $\mathrm{N}$ & $\mathrm{Y}$ & $\mathrm{N}$ & $\mathrm{N}$ & 8 \\
\hline & $\mathrm{F}$ & 47 & $\mathrm{Y}$ & $\mathrm{Y}$ & BU/SMCP & $\mathrm{Y}$ & $\mathrm{N}$ & $\mathrm{N}$ & $\mathrm{Y}$ & $\mathrm{N}$ & 8 \\
\hline & F & 20 & $\mathrm{~N}$ & $\mathrm{Y}$ & $\mathrm{N}$ & $\mathrm{Y}$ & $\mathrm{N}$ & $\mathrm{N}$ & $\mathrm{Y}$ & $\mathrm{N}$ & 5 \\
\hline \multirow[t]{3}{*}{6} & M & 59 & $\mathrm{Y}$ & $\mathrm{N}$ & $\mathrm{N}$ & $\mathrm{Y}$ & $\mathrm{N}$ & $\mathrm{Y}$ & $\mathrm{Y}$ & $\mathrm{N}$ & 7 \\
\hline & $\mathrm{F}$ & 28 & $\mathrm{Y}$ & $\mathrm{N}$ & $\mathrm{N}$ & Y & $\mathrm{N}$ & $\mathrm{Y}$ & $\mathrm{Y}$ & $\mathrm{N}$ & 6 \\
\hline & $\mathrm{F}$ & 31 & $\mathrm{Y}$ & $\mathrm{N}$ & $\mathrm{N}$ & $\mathrm{Y}$ & $\mathrm{N}$ & $\mathrm{Y}$ & $\mathrm{Y}$ & $\mathrm{N}$ & 7 \\
\hline \multirow[t]{3}{*}{7} & $\mathrm{~F}$ & 63 & $\mathrm{Y}$ & $\mathrm{N}$ & $\mathrm{N}$ & $\mathrm{Y}$ & $\mathrm{N}$ & $\mathrm{Y}$ & $\mathrm{N}$ & $\mathrm{Y}$ & 7 \\
\hline & $\mathrm{F}$ & 61 & $\mathrm{Y}$ & $\mathrm{N}$ & $\mathrm{N}$ & $\mathrm{Y}$ & $\mathrm{N}$ & $\mathrm{N}$ & $\mathrm{Y}$ & $\mathrm{N}$ & 6 \\
\hline & $\mathrm{F}$ & 36 & $\mathrm{Y}$ & $\mathrm{N}$ & $\mathrm{CP}$ & $\mathrm{Y}$ & $\mathrm{N}$ & $\mathrm{N}$ & $\mathrm{N}$ & $\mathrm{N}$ & 8 \\
\hline \multirow[t]{3}{*}{9} & M & 73 & $\mathrm{Y}$ & $\mathrm{N}$ & $\mathrm{CP}$ & $\mathrm{Y}$ & $\mathrm{Y}$ & $\mathrm{Y}$ & $\mathrm{N}$ & $\mathrm{N}$ & 9 \\
\hline & $\mathrm{M}$ & 38 & $\mathrm{Y}$ & $\mathrm{N}$ & BU/SMCP & Y & Y & $\mathrm{Y}$ & $\mathrm{N}$ & $\mathrm{Y}$ & 9 \\
\hline & M & 8 & $\mathrm{Y}$ & $\mathrm{N}$ & SMCP & $\mathrm{N}$ & $\mathrm{N}$ & $\mathrm{N}$ & $\mathrm{N}$ & $\mathrm{N}$ & 6 \\
\hline
\end{tabular}

RH/RD, retinal holes or detachments; CP, cleft palate; BU, bifud uvula; SMCP, submucous CP; RS, Robin sequence; SNHL, sensorineural hearing loss; HTm, hyperextensible tympanic membrane; EODJD, early-onset degenerative joint disease; Y, present; $\mathrm{N}$, absent; ${ }^{*}$ ), not determined.

type correlations will have to be done on patients with a clinical diagnosis of Stickler syndrome to clarify the significance of these differences.

\section{Acknowledgments}

This work was supported by the Intramural Research Programs of the National Human Genome Research Institute and the National Institute on Aging, the Warren G. Magnuson Clinical Center of the National Institutes of Health, and intramural research fund Z01 DC 000060-01 from the National Institute on Deafness and Other Communication Disorders. The authors thank the patients and families for their participation in this research and reserve special gratitude for those who gave permission to use their photographs in the publication. The authors also thank Ti Lin for her excellent technical assistance with molecular studies.

\section{References}

1. Stickler GB, Belau PG, Farrell FJ, Jones JD, Pugh DG, Steinberg AG et al. Hereditary progressive arthroophthalmopathy. Mayo Clin Proc 1965;40:433-455.

2. Stickler GB, Pugh DG. Hereditary progressive arthroophthalmopathy, II: Additional observations, a hearing defect, and a report of a similar case. Mayo Clin Proc 1967;42:495-5000.

3. Opitz JM, France T, Hermann J, Spranger JW. The Stickler syndrome. N Engl J Med 1972;286:546-547.

4. Hermann J, France TD, Spranger JW, Opitz JM, Wiffler C. The Stickler syndrome (hereditary arthroophthalmopathy). Birth Defects Orig Artic Ser 1975;11:76-103.

5. Liberfarb RM, Hirose T, Holmes LB. The Wagner-Stickler syndrome. J Pediatr 1981; 99:394-399.

6. Liberfarb RM, Goldblatt A. Prevalence of mitral valve prolapse in the Stickler syndrome. Am J Med Genet 1986;24:387-392.

7. Lucarini JW, Liberfarb RM, Eavey RD. Otolaryngological manifestations of the Stickler syndrome. Int J Pediatr Otolaryngol 1987;14:215-222.

8. Popkin JS, Polemeno RC. Stickler syndrome (hereditary progressive arthroophthalmopathy). Can Med Assoc J 1974;111:1071-1076.

9. Rose PS, Levy HP, Johnston JJ, Griffith AJ, Liberfarb RM, Francomano CA. Proposed diagnostic criteria for Stickler syndrome [abstract]. Am J Hum Genet 2000; 67:S56. 


\section{Stickler syndrome: Genotype/phenotype correlation}

10. Rose P, Ahn N, Levy H, Davis J, Liberfarb R, Nallamshetty L et al. Thoracolumbar spine abnormalities in Stickler syndrome. Spine 2001;26:403-409.

11. Rose P, Ahn N, Levy H, Ahn U, Davis J, Liberfarb R et al. The hip in the Stickler syndrome. J Pediatr Orthop 2001;21:657-663.

12. Seery CM, Pruett RC, Liberfarb RM, Cohen BZ. Distinctive cataract in the Stickler syndrome. Am J Ophthalmol 1990;110:143-148.

13. Szymko-Bennett YM, Mastroianni MA, Shotland LI, Davis J, Ondrey FG, Balog JZ et al. Auditory dysfunction in the Stickler syndrome. Arch Otolaryngol Head Neck Surg 2001;127:1061-1068.

14. Weingeist TA, Hermsen V, Hanson JW, Bumsted RM, Weinstein SI, Olin WH. Ocular and systemic manifestations of Stickler's syndrome: a preliminary report. Birth Defects Orig Artic Ser 1982;XVIII:539-560.

15. Wilkin DJ, Mortier GR, Johnson CL, Jones MC, De Paepe A, Shohat M et al. Correlation of linkage data with phenotype in eight families with Stickler syndrome. Am J Med Genet 1998;80:121-127.

16. Wilkin DJ, Liberfarb RM, Davis J, Levy H, Cole WG, Francomano CA et al. Rapid determination of COL2A1 mutations in individuals with Stickler syndrome. Am J Med Genet 2000;94:141-148.

17. Zlotogora J, Sagi M, Schuper A, Leiba H, Merin S. Variability of Stickler syndrome. Am J Med Genet 1992;42:337-339.

18. Francomano CA, Liberfarb RM, Hirose T, Maumenee IH, Streeten EA, Myers DA et al. The Stickler syndrome: evidence for close linkage to the structural gene for type II collagen. Genomics 1987;1:293-296.

19. Ahmad NN, Ala-Kokko L, Knowlton RG, Weaver EJ, Maguire EJ, TasmanW et al. A stop codon in the gene for type II procollagen (COL2A1) causes one variant of arthro-ophthalmopathy (the Stickler syndrome) [abstract]. Am J Hum Genet 1990; 47:A206.

20. Ahmad NN, Ala-Kokko L, Knowlton RG, Jimenez SA, Weaver EJ, Maguire JL et al. Stop codon in the procollagen II gene (COL2A1) in a family with the Stickler syndrome (arthro-ophthalmopathy). Proc Natl Acad Sci U S A 1991;88:6624-6627.

21. Brown DM, Nichols BE, Weingeist TA, Sheffield VC, Kimura AE, Stone EM. Procollagen II gene mutation in Stickler syndrome. Arch Ophthalmol 1992;110:15891593.

22. Ahmad NN, McDonald-McGinn DM, Zackai EH, Knowlton RG, LaRossa D, Di Mascio J et al. A second mutation in type II procollagen gene (COL2A1) causing Stickler syndrome is also a premature termination codon. Am J Hum Genet 1993; 52:39-45.

23. Ritvaniemi P, Hyland J, Kivirikko KI, Prokop DJ, Ala-Kokko L. A forth example suggests that premature termination codons in the COL2A1 gene are a common cause of the Stickler syndrome: analysis of the COL2A1 gene by denaturing gradient electrophoresis. Genomics 1993;17:218-221.

24. Ahmad NN, Dimasio J, Knowlton RG, Tasman WS. Stickler syndrome: a mutation of the non helical 3' end of type II procollagen gene. Arch Ophthalmol 1995;113: 1454-1457.

25. Brown DM, Vandenburgh K, Kimura AE, Weingeist TA, Sheffield VC, Stone EM. Novel frameshift mutations in the procollagen 2 gene (COL2A1) associated with the Stickler syndrome (hereditary arthro-ophthalmopathy). Hum Mol Genet 1995;4:141-142.

26. Williams CJ, Ganguly A, Considine E, McCarron S, Prokop DJ, Walsh-Vockely C et al. A-2 to G transition at the 3'acceptor splice site of IVS17 characteristic of the COL2A1 gene mutations in the original Stickler syndrome kindred. Am J Med Genet 1996;63:461-467.

27. Annunen S, Korkko J, Czarny M, Warman ML, Brunner HG, Kaariainen $\mathrm{H}$ et al. Splicing mutations of 54-bp exons in the COL11A1 gene cause Marshall/Stickler syndrome, but other mutations cause overlapping Marshall/Stickler phenotypes. Am J Hum Genet 1999;65:974-983.

28. Richards AJ, Baguely DM, Yates JRW, Lane C, Nicol M, Harper PS et al. Variations in the vitreous phenotype of Stickler syndrome can be caused by different amino acid substitutions in the X position of the type II collagen Gly-X-Y triple helix. Am J Hum Genet 2000;67:1083-1094.

29. Richards AJ, Martin S, Yates JRW, Scott JD, Baguely DM, Pope FM et al. COL2A1 exon 2 mutations: relevance to the Stickler and Wagner syndromes. Br J Ophthalmol 2000;84:364-371.

30. Freddi S, Savarirayan R, Bateman JF. Molecular diagnosis of Stickler syndrome: a COL2A1 stop codon mutation screening strategy that is not compromised by mutant mRNA instability. Am J Med Genet 2000;90:398-406.
31. Liberfarb R, Levy H, Davis J, Balog J, Rose P, Wilkin D et al. Comparison of phenotypes in families with Stickler syndrome resulting from mutations in COL2A1 [abstract]. Genet Med 2001;3:218(12)

32. Spranger J, Winterpacht A, Zabel B. The type II collagenopathies: a spectrum of chondrodysplasias. Eur J Pediatr 1994;153:56-65

33. Knowlton RG, Weaver EJ, Struyk AF, Knobloch AF, King RA, Norris K et al. Genetic linkage analysis of hereditary arthro-ophthalmopathy (Stickler syndrome) and the type II procollagen gene. Am J Hum Genet 1989;45:681-688.

34. Fryer AE, Upadhyaya M, Littler M, Bacon P, Watkins D, Tsipouras P. Exclusion of COL2A1 as a candidate gene in a family with Wagner-Stickler syndrome. $J$ Med Genet 1990;27: 91-93.

35. Vintiner GM, Temple IK, Middletown-Price HR, Baraitser M, Malcolm S. Genetic and clinical heterogeneity of Stickler syndrome. J Med Genet 1991;41:44-48.

36. Bonaventure J, Phillipe C, Plessis G, Vigneron J, Lasselin C, Gilgenkrantz S. Linkage study in a large pedigree with Stickler syndrome: exclusion of COL2A1 as the mutant gene. Hum Genet 1992;90:164-168.

37. Vikkula M, Mariman EC, Lui VC, Zhidkova NI, Tiller GE, Goldring MB et al Autosomal dominant and recessive osteochondrodysplasias associated with the COL11A2 locus. Cell 1995;80:431-437.

38. Martin S, Richards AJ, Yates JR, Scott SD, Pope M, Snead MP. Stickler syndrome: further mutations in COL11A1 and evidence for additional locus heterogeneity. Eur J Hum Genet 1999;7:807-814.

39. Richards AJ, Yates JRW, Williams R, Payne SJ, Pope FM, Scott JD et al. A family with Stickler syndrome type 2 has a mutation in the COL11A1 gene resulting in the substitution of glycine by valine in alpha 1 (XI) collagen. Hum Mol Genet 1996;5: 1339-1343.

40. Sirko-Osada DA, Murray MA, Scott JA, Lavery MA, Warman ML, Robin NH. Stickler syndrome without eye involvement is caused by mutations in COL11A2, the gene encoding the alpha2 (XI) chain of type XI collagen. J Pediatr 1998;132:368-371.

41. Snead MR, Yates JRW, Pope FM, Temple IK, Scott JD. Masked confirmation of linkage between type I congenital vitreous anomaly and COL2A1 in Stickler syndrome. Arch Clin Exp Ophthalmol 1996;234:720-721.

42. Snead MP, Yates JR. Clinical and molecular genetics of Stickler syndrome. J Med Genet 1999;36:353-359.

43. Online Mendelian Inheritance in Man. Stickler syndrome, type II. MIM number 184840: 7/12/99. World Wide Web URL: http://www.ncbi.nlm.nih.gov/omim/.

44. Online Mendelian Inheritance in Man. Stickler syndrome, type I. MIM number 108300. 2/25/00. World Wide Web URL: http://www.ncbi.nlm.nih.gov/omim/.

45. Online Mendelian Inheritance in Man. Stickler syndrome, type III. MIM Number 604841. 4/16/00. World Wide Web URL: http://www.ncbi.nlm.nih.gov/omim/.

46. Rosler G. Progression of hearing loss caused by occupational noise. Scand Audio 1994;23(1):13-37.

47. Morrell CH, Gordon-Salant S, Pearson JD, Brant LJ, Fozard JL. Age- and genderspecific reference ranges for hearing level and longitudinal changes in hearing level. J Acoust Soc Am 1006;100:1949-1967.

48. Jerger J. Clinical experience with impedance audiometry. Arch Otolaryngol 1970;92: 311-324.

49. Jerger J, Jerger S, Mauldin L. Studies in impedance audiometry, I: normal and sensorineural ears. Arch Otolaryngol 1972;96:513-523.

50. Margolis RH, Heller JW. Screening tympanometry: criteria for medical referral. Audiology 1987;26:197-208

51. Beighton P, editor. McKusick's heritable disorders of connective tissue. 5th ed. St Louis: Mosby, 1993:199-206.

52. Cobb JR. Outline for the study of scoliosis. Instr Course Lect 1948;5:261-275.

53. Sorensen KH. Scheuermann's juvenile kyphosis: clinical appearance, radiology, aetiology and prognosis. Copenhagen: Munksgaard, 1964.

54. Freed LA, Levy D, Levine RA, Larson MG, Evans JC, Fuller DL et al. Prevalence and clinical outcome of mitral valve prolapse. N Engl J Med 1999;341:1-7.

55. Horton WA. Molecular genetics of human chondrodysplasias. Growth Genet Horm 1997;13:49-55.

56. Stickler GB, Hughes W, Houchin P. Clinical features of hereditary progressive ar throophthalmopathy (Stickler syndrome): a survey. Genet Med 2001;3:192-196. 